\title{
Short communication: Varying dietary dry matter concentration through water addition: Effect on nutrient intake and sorting of dairy cows in late lactation
}

\author{
J. A. Fish and T. J. DeVries ${ }^{1}$ \\ Department of Animal and Poultry Science, University of Guelph, Kemptville Campus, 830 Prescott Street, Kemptville, ON, K0G 1J0, Canada
}

\begin{abstract}
The objective of this study was to determine if feed sorting can be reduced and if nutrient consumption can be limited in late-lactation cows through water addition to a nutrient-dense total mixed ration (TMR) with a dry matter (DM) content greater than $60 \%$. Twelve lactating Holstein cows $(214.8 \pm 28.5 \mathrm{~d}$ in milk) were exposed to 2 diets in a crossover design with 28 -d periods. Diets had the same ingredient composition and differed only in DM percentage, which was reduced by the addition of water. Treatment diets were (1) dry TMR (61.7\% DM) and (2) wet TMR (51.9\% DM). Dry matter intake and milk production (4\% fat-corrected milk; FCM) were recorded for the last $14 \mathrm{~d}$ of each treatment period. For the final $4 \mathrm{~d}$ of each period, fresh feed and orts were sampled for particle size analysis and subsequent calculation of sorting activity (expressed as a percentage of predicted intake). Adding water to the diet tended to decrease the amount of DM in the fine particle fraction, increase starch concentration in the longer ration particles, and reduce starch concentration in the shortest ration particles. All cows sorted against long ration particles; the extent of this sorting did not differ between the dry and wet treatments (72.9 vs. $77.6 \%$ ). There tended to be more sorting for fine ration particles on the dry diet compared with the wet (106.3 vs. $104.0 \%)$. Water addition had no effect on production, with similar DMI (27.9 vs. $26.5 \mathrm{~kg} / \mathrm{d}), 4 \%$ FCM (28.7 vs. $27.6 \mathrm{~kg} / \mathrm{d}$ ), and efficiency of production (0.98 vs. $1.00 \mathrm{~kg}$ of $4 \% \mathrm{FCM} / \mathrm{kg}$ of DMI) between the dry and wet treatments. Adding water to a TMR with greater than $60 \%$ DM containing primarily haylage and corn silage forage sources may change ration particle DM distribution and particle starch content, possibly contributing to less sorting for the smallest ration particles. This research does not provide evidence that water addition to such a TMR can effectively limit DMI in late-lactation cows and, thus, improve efficiency of milk production.
\end{abstract}

Key words: dry matter, late lactation, sorting

Received May 4, 2011.

Accepted October 18, 2011.

${ }^{1}$ Corresponding author: tdevries@uoguelph.ca

\section{Short Communication}

Dairy cows do not always consume a TMR as it is formulated for them. Cows will selectively consume (sort) against the long forage particles and in favor of the smaller concentrate particles in the ration (Leonardi and Armentano, 2003). Water addition to a dry TMR has been proposed as a technique to reduce the degree of feed sorting (Shaver, 2002). In an experiment conducted by Leonardi et al. (2005), the degree of sorting against longer particles and preferential sorting of short particles were decreased when water was added to a dry TMR (reducing DM content from 81 to $64 \%$ ). The diet used in that study was much drier than the typical TMR given to a high-producing dairy cow (40 to $60 \%$ DM; Eastridge, 2006). Recent studies have shown, however, that sorting may increase when adding water to a higher-moisture TMR. Miller-Cushon and DeVries (2009) found that when adding water to such a TMR (reducing DM content from 58 to 48\%), feed sorting behavior was increased. In that study, DMI was reduced on the wetter ration; those researchers postulated that this was likely due to the filling effect of the ration, given that the cows consumed $10 \%$ more, on an as-fed basis, on the wetter ration. In a subsequent study by Felton and DeVries (2010), similar effects on sorting and DMI were found when TMR DM concentration was reduced from 56 to 51 to $44 \%$. Those researchers found that production efficiency increased in this situation because the water addition limited the intake of a ration that was formulated to sustain a higher level of production than that which the cows were producing. It is hypothesized that this could be beneficial for the late-lactation dairy cow consuming a diet that is much higher in nutrient density than is necessary for their level of production (Felton and DeVries, 2010), a situation that occurs on many farms that still feed a one-group TMR to the entire herd. Increased sorting in such a situation would not be beneficial; thus, to achieve such a reduction in intake and improvement in efficiency, a drier ration $(>60 \% \mathrm{DM})$ would need to be used to prevent any increase in sorting with water addition.

The objective of this study was, therefore, to determine if feed sorting can be reduced and if nutrient con- 
sumption can be limited in late-lactation cows through water addition to a high-production TMR with a DM content $>60 \%$. The hypothesis was that the addition of water to a TMR that is $>60 \% \mathrm{DM}$ and balanced for high production would reduce feed sorting but also limit total DMI and, thus, limit nutrient intake in latelactation cows.

Twelve lactating Holstein dairy cows, including 3 primiparous and 9 multiparous (parity $=2.33 \pm 1.37$; mean $\pm \mathrm{SD}$ ), were used in this study. The animals were $214.8 \pm 28.5$ (mean \pm SD) DIM at the beginning of the data collection period and had an average BCS of 3.31 \pm 0.30 (according to Ferguson et al., 1994). The cows were housed together in a tie-stall barn located at the University of Guelph, Kemptville Campus Dairy Education and Research Centre (Kemptville, ON, Canada). Cows were managed according to the guidelines set by the Canadian Council on Animal Care (CCAC, 2009). Each cow was individually housed in a tie-stall with ad libitum water (via individual water bowls) and feed (via a feed bunk containing removable dividers separating adjacent cows' feed). Cows were milked in their stalls twice daily at 0500 and $1600 \mathrm{~h}$. The cows were fed a TMR (Table 1) once daily at $1000 \mathrm{~h}$. Individual orts were removed and weighed before feed delivery. Cows were given a 2 -h exercise period (0800 to $1000 \mathrm{~h}$ ) each day in an outdoor dry lot pen. The experiment was conducted from May 21 to July 15, 2010. The average environmental temperature during the collection periods was $21.5 \pm 3.6^{\circ} \mathrm{C}$.

Cows were divided into 2 groups of 6 , which were balanced according to DIM, milk production, and parity, and then randomly assigned to 1 of the 2 treatments. The cows were exposed, in a crossover design with 28-d periods, to each of 2 treatments (Tables 1 and 2): (1) control TMR (dry diet; target $63 \% \mathrm{DM}$ ) and (2) control TMR with added water (wet diet; target $53 \% \mathrm{DM}$ ). This diet was formulated to meet the nutrient requirements of lactating dairy cows producing 40 $\mathrm{kg} / \mathrm{d}$ (NRC, 2001). Dietary ingredients were mixed for approximately $10 \mathrm{~min}$ in a TMR mixer wagon (Jaylor 4425, Jaylor Fabricating, Orton, ON, Canada). After mixing, the ration was transferred to a feed cart (WIC MDR-55, Ideal Machinery Inc., Wickham, QC, Canada) from which the cows were fed. For the wet diet, water was added into the feed cart and then thoroughly mixed with the feed for $10 \mathrm{~min}$, and delivered to the cows in that treatment. To decrease the dietary DM concentration from approximately 60 to $54 \%$ for the wet treatment, the amount of water added constituted $25 \%$ of the diet (DM basis). Prior to feed delivery, mixing times of both treatment rations within the automatic feeder and feed cart were similar. The amount of feed offered was adjusted daily to ensure approximately $15 \%$ orts $($ actual $=11.5 \pm 7.6 \%$; mean $\pm \mathrm{SD})$.

Representative samples of the treatment TMR and individual orts of each cow were taken daily for the last $14 \mathrm{~d}$ of each treatment period to determine DM and nutrient concentration. Duplicate samples of TMR and individual orts for each cow were taken during the last $4 \mathrm{~d}$ of each treatment period for particle size separation. Additionally, on d 1, 8, 15, and 22 of each treatment period, duplicate samples of the dietary components were taken for particle size and chemical analysis. All samples were immediately frozen at approximately $-20^{\circ} \mathrm{C}$ until they were further analyzed. Samples for particle size separation were separated using a 3-screen (19-, 8-, and 1.18-mm) Penn State Particle Separator (PSPS; Kononoff et al., 2003). This device separated the particles into 4 fractions: long $(>19 \mathrm{~mm})$, medium $(<19$ and $>8 \mathrm{~mm})$, short $(<8$ and $>1.18 \mathrm{~mm})$, and fine $(<1.18 \mathrm{~mm})$ particles. Each separated fraction, as well as the samples taken for DM and chemical analysis, was oven-dried at $55^{\circ} \mathrm{C}$ for $48 \mathrm{~h}$ and then ground to pass through a 1-mm screen (Brinkmann Mill, Brinkmann Instruments Co., Westbury, NY). These samples, plus

Table 1. Ingredient and chemical composition of the basal diet

\begin{tabular}{lc}
\hline Composition & Diet \\
\hline Ingredient, \% of DM $^{1}$ & \\
Corn silage $^{1}$ & 27.2 \\
Alfalfa haylage $^{2}$ & 27.1 \\
High-moisture corn $^{3}$ Concentrate pellet & 25.7 \\
Chemical composition $^{4}$ & 20.0 \\
OM, \% of DM & \\
CP, \% of DM & $92.9 \pm 0.4$ \\
ADF, \% of DM & $16.3 \pm 0.9$ \\
NDF, \% of DM & $18.2 \pm 0.6$ \\
Fat, \% of DM & $29.1 \pm 0.7$ \\
NFC, \% of DM & $1.7 \pm 0.1$ \\
Starch, \% of DM & $45.8 \pm 1.1$ \\
NE $_{\mathrm{L}}, \mathrm{Mcal} / \mathrm{kg}$ of DM & $33.2 \pm 1.4$ \\
\hline
\end{tabular}

${ }^{1}$ Corn silage had a DM of $43.8 \pm 5.3 \%$ and chemical composition (DM basis) of $8.2 \pm 0.3 \% \mathrm{CP}, 19.7 \pm 0.4 \% \mathrm{ADF}$, and $33.7 \pm 2.1 \mathrm{NDF}$. Particle size distribution of corn silage (DM basis) was $4.3 \pm 1.1 \%$ long, $61.9 \pm 1.9 \%$ medium, $28.3 \pm 1.8 \%$ short, and $5.5 \pm 1.2 \%$ fine particles.

${ }^{2}$ Alfalfa haylage had a DM of $62.8 \pm 1.1 \%$ and chemical composition (DM basis) of $16.5 \pm 0.6 \% \mathrm{CP}, 33.9 \pm 0.4 \% \mathrm{ADF}$, and $50.4 \pm 0.1$ NDF. Particle size distribution of alfalfa haylage (DM basis) was 17.0 $\pm 7.8 \%$ long, $49.1 \pm 3.9 \%$ medium, $24.6 \pm 4.9 \%$ short, and $9.3 \pm 2.2 \%$ fine particles.

${ }^{3}$ Supplied by Ritchie Feed \& Seed Inc. (Ottawa, ON, Canada), containing (as-is basis): $25.3 \%$ corn gluten meal, $24.2 \%$ soybean meal, $24.1 \%$ Tri-Pro Gold (Tri-County Protein Corp., Winchester, ON, Canada), $9.9 \%$ canola meal, $5.3 \%$ ground limestone, $5.0 \%$ trace mineral/vitamin premix, $4.3 \%$ sodium bicarbonate, $1.9 \%$ cobaltized-iodized salt.

${ }^{4}$ Values were obtained from chemical analysis of TMR samples; OM = $100-\%$ ash $; \mathrm{NFC}=100-(\% \mathrm{CP}+\% \mathrm{NDF}+\%$ fat $+\%$ ash $) ; \mathrm{NE}_{\mathrm{L}}$ were calculated based on NRC (2001) equations. 
Table 2. Particle size distribution ${ }^{1}$ and NDF and starch contents of the particle fractions of the treatment diets

\begin{tabular}{|c|c|c|c|c|}
\hline \multirow[b]{2}{*}{ Item } & \multicolumn{2}{|c|}{$\operatorname{Diet}^{2}$} & \multirow[b]{2}{*}{$\mathrm{SE}$} & \multirow[b]{2}{*}{$P$-value } \\
\hline & Dry & Wet & & \\
\hline DM, \% of TMR & 61.7 & 51.9 & 0.02 & $<0.001$ \\
\hline \multicolumn{5}{|l|}{ DM, \% retained on screen } \\
\hline Long & 3.8 & 3.8 & 0.3 & 0.98 \\
\hline Medium & 52.9 & 54.6 & 0.01 & 0.004 \\
\hline Short & 30.6 & 33.6 & 0.7 & 0.19 \\
\hline Fine & 12.7 & 8.0 & 0.3 & 0.06 \\
\hline \multicolumn{5}{|l|}{ NDF, \% of screen DM } \\
\hline Long & 50.1 & 45.4 & 1.7 & 0.3 \\
\hline Medium & 32.5 & 32.0 & 0.04 & 0.06 \\
\hline Short & 26.4 & 27.0 & 0.07 & 0.11 \\
\hline Fine & 16.9 & 17.5 & 0.4 & 0.5 \\
\hline \multicolumn{5}{|l|}{ Starch, \% of screen DM } \\
\hline Long & 14.5 & 18.5 & 0.4 & 0.09 \\
\hline Medium & 27.3 & 29.8 & 0.04 & 0.01 \\
\hline Short & 35.3 & 32.7 & 0.03 & 0.01 \\
\hline Fine & 47.3 & 41.0 & 0.6 & 0.08 \\
\hline
\end{tabular}

the dried TMR particle fractions, were sent to Cumberland Valley Analytical Services Inc. (Maugansville, $\mathrm{MD})$ for analysis of $\mathrm{DM}\left(135^{\circ} \mathrm{C}\right.$; AOAC, 2000; method 930.15), ash $\left(535^{\circ} \mathrm{C}\right.$; AOAC, 2000; method 942.05), ADF (AOAC, 2000; method 973.18), NDF with heatstable $\alpha$-amylase and sodium sulfite (Van Soest et al., 1991), fat (AOAC, 2006; method 2003.05), starch (Hall, $2009)$, and $\mathrm{CP}(\mathrm{N} \times 6.25$, AOAC 2000; method 990.03; Leco FP-528 Nitrogen Analyzer, Leco, St. Joseph, MI).

Daily milk production was recorded for each cow during the last $14 \mathrm{~d}$ of each treatment period, using TruTest milk meters (Surge, Mississauga, ON, Canada). Milk samples were taken from each cow from each milking during the last $3 \mathrm{~d}$ of the collection period. These samples were sent to the DHI laboratory (Ontario Dairy Herd Improvement Corp., Guelph, ON, Canada) and analyzed for fat and protein content using a nearinfrared analyzer (Foss System 4000, Foss Electric, Hillerød, Denmark). Milk fat and protein yields (kg/d) were calculated for the last $3 \mathrm{~d}$ of each treatment period based on the product of the milk production yield and milk composition at each milking on those days. For those days, the yield of $4 \% \mathrm{FCM}(\mathrm{kg} / \mathrm{d})$ was calculated $(\mathrm{NRC}, 2001)$ as $0.4 \times$ milk yield $(\mathrm{kg} / \mathrm{d})+15.0$ $\times$ fat yield $(\mathrm{kg} / \mathrm{d})$. Efficiency of milk production was determined by calculating the kilograms of milk or $4 \%$ FCM yield per kilogram of DMI for the last $4 \mathrm{~d}$ of each treatment period. Cow BCS was recorded on a 5-point scale (Ferguson et al., 1994) on d 1, 15, and 28 of each treatment period.

Sorting activity for each fraction of the PSPS was calculated as the actual intake of each fraction expressed as a percentage of the predicted intake of that fraction (Leonardi and Armentano, 2003). The predicted intake of an individual fraction was calculated as the product of the DMI of the total diet multiplied by the DM percentage of that fraction in the fed TMR. Values equal to $100 \%$ indicate no sorting, those $<100 \%$ indicate selective refusals (sorting against), and those $>100 \%$ indicate preferential consumption (sorting for). To test whether sorting of the experimental diets occurred, sorting activity for each fraction of the PSPS was summarized by treatment and tested for a difference from 100 using $t$-tests. All data were then analyzed using the MIXED procedure of SAS (SAS Institute, 2003). The final model included the fixed effects of period, order, and treatment, the random effect of cow within order, and the residual error. Cow BCS were included as a covariate in the model; however, these were not significant and were not included in the final model. To determine the effect that feed sorting had on production parameters, sorting data were individually included as a continuous linear effect in the above-mentioned model; only those significant effects are reported. All values reported are least squares means. Significance was declared at $P \leq 0.05$, and trends reported if 0.05 $<P \leq 0.10$.

To address the objective of this study, 2 treatment diets were tested; these diets had the same ingredient and chemical composition (Table 1) but differed in DM concentration by approximately $10 \%$ (Table 2) due to the addition of water to the TMR. The addition of water also altered the particle size distribution of the TMR: an increased amount of DM was retained in the 
Table 3. Effect of dietary treatments on the sorting (\%) of long, medium, short, and fine particles ${ }^{1}$ and intake ${ }^{2}$ of feed and nutrients, and nutrient composition of diet consumed for treatment diets

\begin{tabular}{lcccc}
\hline & \multicolumn{2}{c}{ Diet $^{3}$} & & \\
\cline { 2 - 3 } Item & Dry & Wet & SE & P-value \\
\hline Sorting, ${ }^{4} \%$ & & & & \\
$\quad$ Long & $72.9^{*}$ & $77.6^{*}$ & 4.5 & 0.47 \\
Medium & 100.1 & 99.8 & 0.4 & 0.59 \\
Short & 100.7 & $102.1^{*}$ & 1.0 & 0.32 \\
Fine & $106.3^{*}$ & $104.0^{*}$ & 1.0 & 0.10 \\
Intake & 27.9 & & & 0.38 \\
DMI, kg/d & 43.6 & 26.5 & 1.1 & 0.038 \\
Wet matter intake, kg/d & 15.7 & 49.6 & 1.9 & $<0.001$ \\
Feed water intake, kg/d & 7.9 & 23.1 & 0.9 & 0.68 \\
NDF intake, kg/d & 28.4 & 7.7 & 0.3 & $<0.001$ \\
cNDF, ${ }^{*} \%$ of DM & 9.3 & 29.1 & 0.06 & 0.45 \\
Starch intake, $\mathrm{kg} / \mathrm{d}$ & 33.1 & 3.9 & 0.4 & $<0.001$ \\
cStarch, ${ }^{6} \%$ of DM & & 3.4 & 0.05 & \\
\hline
\end{tabular}

${ }^{1}$ Particle size determined by Penn State Particle Separator, which has a 19-mm screen (long), 8-mm screen (medium), 1.18-mm screen (short), and a pan (fine).

${ }^{2}$ Data are averaged over $7 \mathrm{~d}$ for 12 cows on each treatment.

${ }^{3}$ Dry $=$ control diet without water added; Wet $=$ control diet plus $25 \%$ water added (DM basis).

${ }^{4}$ Sorting $\%=100 \times(\mathrm{n} \mathrm{DMI} / \mathrm{n}$ predicted DMI), where $\mathrm{n}=$ particle fraction (long, medium, short, or fine).

Sorting values equal to $100 \%$ indicate no sorting, $<100 \%$ indicate selective refusals (sorting against), and

$>100 \%$ indicate preferential consumption (sorting for). Data are averaged over $4 \mathrm{~d}$ for 12 cows on each treatment.

${ }^{5} \mathrm{cNDF}=\mathrm{NDF}$ concentration of diet consumed $=(\mathrm{NDF}$ intake $/ \mathrm{DMI}) \times 100$.

${ }^{6} \mathrm{cStarch}=$ starch concentration of diet consumed $=($ starch intake $/ \mathrm{DMI}) \times 100$.

${ }^{*} P<0.05$ (difference in sorting values from $100 \%$ ).

medium particle fraction, and a lesser amount of DM tended to be retained in the finest particle fraction (Table 2). Changes in ration particle distribution with water addition have been previously observed with rations of various compositions (Leonardi et al., 2005; Miller-Cushon and DeVries, 2009; Felton and DeVries, 2010). These changes can be attributed to water causing the fine particles, which are higher in starch, to stick to larger particles. Evidence of this is seen in the wet diet of the current study, as it contained a greater proportion of starch in the long and medium particles, and less starch in the short and fine particles compared with the dry diet (Table 2).

Cows sorted against long particles and for fine particles across both treatment diets (Table 3). This sorting pattern, and its extent, is typical and indicates, as described previously, that cows were selecting against the longest, fibrous forage particles and selecting for the finest, highly palatable concentrate components (Leonardi and Armentano, 2003; Leonardi et al., 2005). The degree of sorting observed in this study (average $22-27 \%$ refusal of long particles) may have affected rumen $\mathrm{pH}$ (e.g., decrease in maximum rumen $\mathrm{pH}$ of 0.5 for $25 \%$ difference in sorting behavior; DeVries et al., 2008) across all cows on both treatments. It is not surprising, therefore, that we found, similar to DeVries et al. (2011), that greater selection against the longest ration particles was associated with lower milk fat percentage [milk fat $\%=0.015 \times$ sorting of long particles $(\%)+2.40 ; P=0.03]$, likely due to effects of depressed rumen $\mathrm{pH}$.

In support of our hypothesis, we observed a tendency for greater sorting for fine particles when cows were fed the dry diet (Table 3). This finding is consistent with Leonardi et al. (2005), who found a decrease in the extent of sorting for the shortest ration particles and against the longest ration particles when reducing the DM content of a ration, through water addition, from approximately 81 to $64 \%$. In the current study, the tendency for a reduction in sorting for the fine particles on the wet diet may be attributable to water causing the smallest ration particles to stick to the longer particles, altering the particle and nutrient distribution of the ration. As there was a tendency for less DM and starch to be found in the fine particle fraction and more starch in the longest particle fraction (Table 2), it may have been more difficult to sort out the more palatable, high-starch, fine particles in the wet diet. Interestingly, the extent of sorting against the long particle fraction did not differ significantly between the diets; however, there was numerically less sorting against the long particles on the wet diet (Table 3). The greatest amount of variability was seen in the sorting of the long particles; in a future study with a larger sample size, and thus 
Table 4. Effect of dietary DM content on milk yield, milk composition, and milk component yield

\begin{tabular}{|c|c|c|c|c|}
\hline \multirow[b]{2}{*}{ Item } & \multicolumn{2}{|c|}{ Diet $^{1}$} & \multirow[b]{2}{*}{$\mathrm{SE}$} & \multirow[b]{2}{*}{$P$-value } \\
\hline & Dry & Wet & & \\
\hline \multicolumn{5}{|l|}{ Milk yield } \\
\hline Milk, ${ }^{2} \mathrm{~kg} / \mathrm{d}$ & 31.6 & 31.1 & 0.9 & 0.69 \\
\hline $4 \% \mathrm{FCM}^{3}, \mathrm{~kg} / \mathrm{d}$ & 28.7 & 27.6 & 0.9 & 0.43 \\
\hline \multicolumn{5}{|l|}{ Milk composition, ${ }^{3} \%$} \\
\hline Fat & 3.55 & 3.51 & 0.15 & 0.85 \\
\hline Protein & 3.55 & 3.55 & 0.06 & 0.96 \\
\hline \multicolumn{5}{|c|}{ Milk component yield, ${ }^{3} \mathrm{~kg} / \mathrm{d}$} \\
\hline Fat & 1.09 & 1.04 & 0.05 & 0.46 \\
\hline Protein & 1.10 & 1.07 & 0.04 & 0.56 \\
\hline \multicolumn{5}{|c|}{ Efficiency of milk production ${ }^{3}$} \\
\hline Milk/DMI, kg/kg & 1.15 & 1.20 & 0.04 & 0.37 \\
\hline $4 \%$ FCM $/ \mathrm{DMI}, \mathrm{kg} / \mathrm{kg}$ & 0.98 & 1.01 & 0.04 & 0.61 \\
\hline
\end{tabular}

greater power, the numerical difference observed might become significant.

Interestingly, in previous studies by our research group (Miller-Cushon and DeVries, 2009; Felton and DeVries, 2010), we observed a higher degree of sorting against the longest ration particles with more water in the ration. The rations used in those studies were similar in composition to that used in the present study, except that the basal diets were slightly lower in DM, and the addition of water did not alter the starch concentrations of the particle fractions in the earlier studies. Miller-Cushon and DeVries (2009) hypothesized that the addition of water to an already high-moisture long particle fraction may have made the particles less palatable and, thus, increased sorting against those particles. In the present study, the tendency for an increased proportion of starch retained in the long particle fraction might have made those particles more palatable, and thus prevented this increase in sorting.

Despite a 1.4-kg numerical decrease in DMI, the addition of water to the basal TMR had no significant effect on DMI (Table 3); other researchers have also shown no effect of water addition on DMI (Robinson et al., 1990; Leonardi et al., 2005). This, however, was contrary to our hypothesis because it contrasts our previous findings, whereby we found linear decreases in DMI with the addition of water to a TMR containing all wet forages (Miller-Cushon and DeVries, 2009; Felton and DeVries, 2010). Similar to those studies, we did find that water addition resulted in a greater amount of wet matter intake as result of greater feed water intake (Table 3). In contrast to that previously observed (Miller-Cushon and DeVries, 2009; Felton and DeVries, 2010), the amount of wet matter intake was probably not high enough to limit fill and thus DMI in the current study. Water addition, at the level used in this study, for cows earlier in lactation with greater DMI may limit DMI; further research is needed to assess this.

Also contrary to our hypothesis, total NDF and starch intakes were not affected by water addition to the diet (Table 3). In previous studies, the addition of water has resulted in reduction in total NDF and starch intakes, corresponding to the decrease in DMI observed (Miller-Cushon and DeVries, 2009; Felton and DeVries, 2010). In the present study, the concentration of NDF and starch of the diet consumed were slightly higher in the wet diet (Table 3), likely due to the sorting for both short and fine particles (high in starch) and the numerically lower, albeit not significant, sorting against long particles (high in NDF) observed on the wet diet.

Treatment had no effect on milk production in this study (Table 4), corresponding to the maintenance of DMI between treatments. Given that, it is also not surprising that treatment had no effect on milk fat and protein percentages or yields, or on the efficiency of milk production. The diet used in this study was formulated to support a level of production for cows earlier in lactation (at 90 DIM producing $40 \mathrm{~kg} / \mathrm{d}$ of milk) with an $\mathrm{NE}_{\mathrm{L}}$ requirement of $41 \mathrm{Mcal} / \mathrm{d}$ (NRC, 2001). Given the actual production level of the cows $(31-32 \mathrm{~kg} / \mathrm{d})$ and average stage of lactation during the study (243 DIM), the $\mathrm{NE}_{\mathrm{L}}$ requirement of the cows was only $34 \mathrm{Mcal} / \mathrm{d}$ (NRC, 2001). Thus, the level of production observed in this study's cows could have been supported by a much lower level of DMI $(20.4 \mathrm{~kg} / \mathrm{d})$ than what was observed. Due to the overconsumption of DM relative to requirement, it is not surprising that cows gained, on average, $0.21 \pm 0.14$ points in BCS over the $56 \mathrm{~d}$ of the study. 
Overall, the results suggest that adding water to a TMR with greater than $60 \%$ DM containing primarily haylage and corn silage forage sources may change ration particle DM distribution and starch content of those particle fractions, possibly contributing to a lesser degree of sorting for the smallest ration particles. This research does not provide evidence that water addition to such a TMR can effectively limit DMI in late-lactation cows and, thus, improve efficiency of milk production.

\section{ACKNOWLEDGMENTS}

We thank the staff and students at the University of Guelph, Kemptville Campus Dairy Education and Research Centre. In particular, we thank Megan Bruce of the University of Guelph, Kemptville Campus, for her technical help. We also thank the Dairy Farmers of Canada (Ottawa, ON, Canada), the Canadian Dairy Commission (Ottawa, ON, Canada), and Agriculture and Agri-Food Canada (Ottawa, ON, Canada) for their financial support of this study. The project also received support from the Ontario Ministry of Agriculture, Food and Rural Affairs (OMAFRA, Guelph, ON, Canada) and from the Canadian Foundation for Innovation (CFI, Ottawa, ON, Canada) and the Ontario Research Fund (Ministry of Research and Innovation, Toronto, ON, Canada).

\section{REFERENCES}

AOAC. 2000. Official Methods of Analysis. Vol. I. 17th ed. Association of Official Analytical Chemists International. Arlington, VA.

AOAC. 2006. Official Methods of Analysis. Vol. I. 18th ed. Association of Official Analytical Chemists International. Arlington, VA.
CCAC. 2009. Guidelines on the Care and Use of Farm Animals in Research, Teaching and Testing. Canadian Council on Animal Care, Ottawa, ON, Canada.

DeVries, T. J., F. Dohme, and K. A. Beauchemin. 2008. Repeated ruminal acidosis challenges in lactating dairy cows at high and low risk for developing acidosis: Feed sorting. J. Dairy Sci. 91:3958 3967.

DeVries, T. J., L. Holsthausen, M. Oba, and K. A. Beauchemin. 2011. Effect of parity and stage of lactation on feed sorting behavior of lactating dairy cows. J. Dairy Sci. 94:4039-4045.

Eastridge, M. L. 2006. Major advances in applied dairy cattle nutrition. J. Dairy Sci. 89:1311-1323.

Felton, C. A., and T. J. DeVries. 2010. Effect of water addition to a total mixed ration on feed temperature, feed intake, sorting behavior and milk production of dairy cows. J. Dairy Sci. 93:2651-2660.

Ferguson, J. D., D. D. Galligan, and N. Thomsen. 1994. Principal descriptors of body condition score in Holstein cows. J. Dairy Sci. 77:2695-2703.

Hall, M. B. 2009. Analysis of starch, including maltooligosaccharides, in animal feeds: A comparison of methods and a recommended method for AOAC collaborative study. J. AOAC Int. 92:42-49.

Kononoff, P. J., A. J. Heinrichs, and D. R. Buckmaster. 2003. Modification of Penn State forage and total mixed ration particle separator and the effects of moisture content on its measurements. J. Dairy Sci. 86:1858-1863.

Leonardi, C., and L. E. Armentano. 2003. Effect of quantity, quality, and length of alfalfa hay on selective consumption by dairy cows. J. Dairy Sci. 86:557-564.

Leonardi, C., F. Giannico, and L. E. Armentano. 2005. Effect of water addition on selective consumption (sorting) of dry diets by dairy cattle. J. Dairy Sci. 88:1043-1049.

Miller-Cushon, E. K., and T. J. DeVries. 2009. Effect of dietary dry matter concentration on the sorting behavior of lactating dairy cows fed a total mixed ration. J. Dairy Sci. 92:3292-3298.

NRC. 2001. Nutrient Requirements of Dairy Cattle. 7th rev. ed. Natl. Acad. Sci., Washington, DC.

Robinson, P. H., P. L. Burgess, and R. E. McQueen. 1990. Influence of moisture content of mixed rations on feed intake and milk production of dairy cows. J. Dairy Sci. 73:2916-2921.

SAS Institute. 2003. SAS Users Guide. SAS Inst. Inc., Cary, NC.

Shaver, R. D. 2002. Rumen acidosis in dairy cattle: Bunk management considerations. Adv. Dairy Technol. 14:241-249.

Van Soest, P. J., J. B. Robertson, and B. A. Lewis. 1991. Methods for dietary fiber, neutral detergent fiber and non-starch polysaccharide in relation to animal nutrition. J. Dairy Sci. 74:3583-3597. 